\title{
CONTROLS OVER LABELING AND ADVERTISING OF ALCOHOLIC BEVERAGES
}

\author{
Wallace A. Russeli*
}

The time has passed when an inveterate toper could excuse his addiction to the bottle by relying upon advertising statements that his particular "tonic" "aids digestion, stimulates and enriches the blood, invigorates the brain, builds nerve tissue, tones up the heart, and prolongs life." He can no longer point to assurances on the bottle that the contents constitute a cure for pulmonary conditions, stomach complaints, la grippe, typhoid, and other low fevers and would render his system, if he drank enough, immune to various diseases, and, if applied externally, would even cure ulcers. ${ }^{1}$ Indeed regulation of labeling and advertising of alcoholic beverages has become an outpost on the advancing frontier of protection of the unwary consumer.

Prior to the repeal of Prohibition, no agency of the Federal Government was provided with statutory authority to regulate the labeling and advertising of alcoholic beverages specifically. Such control as existed in this field was exerted by agencies already overburdened with the task of supervising and correcting practices in the whole range of commerce, such as the Federal Trade Commission and the Food and Drug Administration. ${ }^{2}$ After a long and bitter battle, the question of defining "whisky" under the Food and Drug Act was finally brought before President Taft, who decided, on December 27, I909, that the term "whisky" had traditionally included all potable liquors distilled from grain. This all-embracing definition, of course, afforded no real standard. ${ }^{3}$

* A.B., 1929, Yale University; LL.B., 1932, Harvard University. Attorney, Alcohol Tax Division of Chief Counsel's Office, Bureau of Internal Revenue. Attorney with the Federal Alcohol Control Administration and Federal Alcohol Administration from December, I933 until abolition of the latter agency, July I, 1940 .

${ }_{1}^{1}$ The label statements referred to are drawn from press release of the Food and Drug Administration, dated Feb. 24, I934. Other examples of medicinal claims appearing in advertisements of liquor before Prohibition are: "America's greatest medicine," "Better than all other medicines combined"; "Nursing mothers-build up your strength and the health of your infant by taking an invigorating stimulant"; "Coughs, colds, grippe, asthma, bronchitis, and consumption spcedily cured"; "Good for the kidneysthat concentrated essence of the juniper berry known in its purest form as Gin"; "Many trained nurses advise their patients to order strengthening wines, whiskies, and cordials."

2 The activities of these agencies in connection with the labeling and advertising of alcoholic beverages are discussed infra pp. 655-66o.

${ }^{3}$ The whisky controversy in this country and in England is ably reviewed in a memorandum prepared by E. B. Bowers, an attorney in the former Federal Alcohol Control Administration, entitled Memorandum on the "What is Whisky" Controversy. See also Thonnton, LAw of Food and Drugs (I9I2) $450-46 r$. 
While isolated labeling provisions appeared in the internal revenue laws and regulations, in the main these required labeling information identifying the product for tax purposes and, in most cases, applied to bulk containers which the inquisitive consumer would never see. ${ }^{4}$ There was, however, one important exception-in 1897 Congress passed the Bottling in Bond Act. ${ }^{5}$ This statute permitted certain spirits to be bottled in bond under government supervision, and provided for use on the bottle of a particular kind of internal revenue stamp which served to identify such spirits. Only spirits which had remained in bond for four years (now storage in wooden containers is required), which were produced in one distilling season by the same distiller at the same plant, and reduced to not less than $100^{\circ}$ proof could be bottled in bond. Thus, bottled in bond whisky was the only alcoholic beverage upon which a consumer could rely at all, and even here the protection afforded was extremely limited. Moreover, bottled in bond products were relatively expensive and the fact that wholesalers and retailers could secure whisky in barrels and bottle it themselves left the door wide open to all sorts of frauds, the discovery and correction of which were extremely difficult. The fact that fraud was rampant in this field was well known, ${ }^{6}$ and the theory of caveat emptor still prevailed in spite of isolated attempts to require more informative labeling. During Prohibition mislabeling was stimulated to a degree undreamed of before and many through bitter experience became familiar with the attendant evils.

The repeal of Prohibition occurred on December 5, 1933, when Congress was not in session, and the provisions of the National Industrial Recovery Act, ${ }^{7}$ relating to the regulation of industry under codes of fair competition, were seized upon as a means of controlling the renascent industry in order to prevent a recurrence of the evils which were to a large extent responsible for the advent of Prohibition and the Federal Alcohol Control Administration was established by executive order. ${ }^{8}$ The codes for the various branches of the alcoholic beverages industry each contained provisions with respect to labeling and advertising. ${ }^{9}$ With some slight variations of language, these provisions prohibited industry members from publishing false advertisements and selling misbranded products. Advertisements were deemed to be false if untrue in any particular, or if directly or by ambiguity, omission, or inference they tended to convey a misleading impression. Products were deemed misbranded: ( $x$ ) if not labeled in compliance with the Federal Food and Drugs Act, (2) if the container was made, formed, or filled so as to mislead the purchaser, or if

'E.g., Bur. Int. Rev., Gauging Manual (I938 ed.) $9942,48,56-62,73-86$, and 145 contain requirements with respect to the marking of the barrel heads of bulk spirits.

5 29 StAт. 626 (1897) as amended by 49 StAT. I944 (1936), 26 U. S. C. $\$ \$ 2903,2904$ (Supp. V I940).

"President Taft's Whisky Decision, December 27, I909, contained the following statcment: "It is undoubtedly true that liquor trading has been disgracefully full of frauds upon the public by false labels. ...."

${ }^{7} 48$ Stat. I95 (1933). ${ }^{8}$ Exec. Order No. 6474, Dec. 4, 1933.

${ }^{\circ}$ For these provisions see Distilled Spirits Code, art. V, $\S \S \mathrm{r}, 2$; Distilled Spirits Rectifying Code, art. V, $\$ \S I, 2$; Alcoholic Beverages Importing Code, art. V, $\$$ I, 2; Brewing Code, art. IV, $\$ \S I, 2$; Wine Code, art. V, $\$$ I, 2; Alcoholic Beverage Wholesale Code, art. V, $\$ \S I, 2$, art. VI, $\$ \S 1,2$. 
the contents fell below standards of fill to be prescribed by regulation, (3) if represented as products covered by a standard of identity prescribed by regulations and if they did not conform to such standard, (4) if represented as conforming to a standard of quality prescribed by regulation and if their labels failed to state, if required, such standard correctly, or if they fell below such standard (no regulations were, however, ever issued prescribing standards of quality), and (5) if not labeled in conformity with regulations prescribed.

On February 6, 1934, the Federal Alcohol Control Administration approved a five-page set of distilled spirits labeling regulations of a general nature. Experience, however, quickly proved that any attempt to regulate the labeling of alcoholic beverages by the interpretation of general regulations was doomed to failure. After the issuance of several amendments, a multitude (II5) of interpretations and special regulations dealing with particular subjects, on May I3, I935, the regulations were reissued in pamphlet form, covering 32 pages. $^{10} \mathrm{~A}$ review of the provisions of these regulations is unnecessary since they form the background for the regulations now in force. Almost immediately thereafter, the legislative props upon which the Federal Alcohol Control Administration and its regulations rested were knocked out by the decision of the Supreme Court in the Schechter case on May 27, $1935 .{ }^{11}$

Although the Federal Alcohol Administration Act ${ }^{12}$ was not passed until August 29, 1935, the disintegration of labeling and advertising control in the interim was prevented by the fact that the Bureau of Internal Revenue had already adopted, and was enforcing, some of the Federal Alcohol Control Administration labeling requirements under its authority to control the traffic in containers of distilled spirits. On June 15, 1935, the Bureau's Regulations No. $13^{13}$ were amended to require that all liquor bottles should bear most of the mandatory information theretofore required under the Federal Alcohol Control Administration's regulations (T.D. $45^{60}$ ). Thus distilled spirits labeling controls were continued during the consideration of new legislation by Congress. The new statute was based to a large extent on provisions of the codes of fair competition and the control over labeling and advertising was retained.

Perhaps the best summary of the purposes behind these labeling and advertising provisions of the statute appeared in the statement of Joseph H. Choate, Jr., former Director of the Federal Alcohol Control Administration, at the hearings before the Ways and Means Committee of the House of Representatives: ${ }^{14}$

"Now, the provisions of this bill show that the purpose was to carry that regulation into certain particular fields in which control of interstate commerce in liquors was paramount and necessary. The purpose was to provide such regulations, not laid down

${ }^{10}$ F. A. C. A., Regs. Relating to False Advertising and Misbranding of Distilled Spirits, May 13, 1935.

11295 U. S. 495 (1935).

2249 Stat. 977 (1935) as amended by 49 Stat. 1152 (1936) and 49 Stat. 1964 (1936), 27 U. S. C. $\$ 201$ (Supp. IV 1938).

${ }^{13}$ U. S. Treas. Bur. of Int. Rev., Reg. $x_{3}$ (Traffic in Containers of Distilled Spirits), 26 CoDE Fed. REG., c. I, pt. $\mathrm{x} 75$.

${ }^{14}$ Hearings before the Committee on Ways and Means on H. R. 8539, 74th Cong., xst Sess. (1935) ro. 
in statute, so as to be inflexible, but laid down under the guidance of Congress, under general principles, by a body which could change them as changes were found necessary.

"Those regulations were intended to insure that the purchaser should get what he thought he was getting, that representations both in labels and in advertising should be honest and straightforward and truthful. They should not be confined, as the pure-food regulations have been confined, to prohibitions of falsity, but they should also provide for the information of the consumer, that he should be told what was in the bottle, and all the important factors which were of interest to him about what was in the bottle."

A further statement of the purposes of this legislation appears in the Report of the Ways and Means Committee on the proposed legislation $:^{15}$

"The labeling and advertising provisions (sec. 5(e) and (f)) prohibit the use of interstate channels when labeling or advertising of distilled spirits, wine, or malt beverages does not conform to regulations, with the force and effect of law, prescribed by the Administrator. Definite standards are laid down for these regulations. The regulations are not only required to prohibit labeling and advertising that is false, misleading, obscene, or indecent, or that disparages competitors' products, but must also provide for the prevention of deception of the consumer with respect to the product or its quality. They must also prohibit, regardless of their truth, statements relating to age, manufacturing process, analyses, guaranties, and scientific or irrelevant matters that the Administrator finds likely to mislead the consumer, and must make provision for informing the consumer adequately as to the identity and quality of the product, its alcoholic content, the net contents of the package, and the person responsible for the package or the advertisement."

Conforming to these statements, ${ }^{16}$ the statute contemplates not only the elimination from advertising and labeling material of all statements that are deceptive or misleading, but also the furnishing of information to the consumer which will ad-

\footnotetext{
${ }^{15}$ H. R. REP. No. 1542, 74th Cong., Ist Sess. (1935) 12.
}

${ }^{10}$ The legislative standards contained in the Act read: ". . . such regulations, to be prescribed by the Administrator, with respect to packaging, marking, branding, and labeling and size and fill of container (I) as will prohibit deception of the consumer with respect to such products or the quantity thercof and as will prohibit, irrespective of falsity, such statements relating to age, manufacturing processes, analyses, guarantees, and scientific or irrelevant matters as the Administrator finds to be likely to mislead the consumer; (2) as will provide the consumer with adequate information as to the identity and quality of the products, the alcoholic content thereof (except that statements of, or statements likely to be considered as statements of, alcoholia content of malt beverages are hereby prohibited unless required by State law and except that, in the case of wines, statements of alcoholic content shall be required only for wines containing more than 14 per centum of alcohol by volume), the net contents of the package, and the manufacturer or bottler or importer of the product; (3) as will require an accurate statement, in the case of distilled spirits (other than cordials, liqueurs, and specialties)' produced by blending or rectification, if neutral spirits have been' used in the production thereof, informing the consumer of the percentage of neutral spirits so used and of the name of the commodity from which such neutral spirits have been distilled, or, in the case of neutral spirits or of gin produced by a process of continuous distillation, the name of the commodity from which distilled; (4) as will prohibit statements on the label that are disparaging of a competitor's products or are false, misleading, obscene, or indccent; and (5) as will prevent deception of the consumer by use of a trade or brand name that is the name of any living individual of public prominence, or existing private or public organization, or is a name that is in simulation or is an abbreviation thereof, and as will prevent the use of a graphic, pictorial, or cmblematic representation of any such individual or organization, if the use of such name or representation is likely falsely to lead the consumer to believe that the product has been indorsed, made, or used by, or produced for, or under the supervision of, or in accordance with the specifications of, such individual or organization. ..." $\$ 5(e)$, Federal Alcohol Administration ACT. See $\$ 5(f)$ for similar standards applicable to advertising regulations. 
vise him of the identity, quality, net contents, alcoholic content (except in the case of malt beverages or of wine containing not more than $14 \%$ of alcohol by volume), the name of the person responsible for the product, and the amount and source of the neutral spirits, if any, in the product. The statute thus went much farther in positive demands upon producers that they advise the public of the nature of their products than any earlier legislation with respect to liquor or any other product not actually dangerous.

Filling in the details under these legislative standards, the Federal Alcohol Administration issued regulations governing the labeling and advertising of wine, distilled spirits, and malt beverages, respectively. These regulations will be considered in detail later. It should perhaps be noted here, however, that in the only cases in which the regulations have been attacked, the statute and the regulations have met with judicial approval. In Arrow Distilleries, Inc. v. Alexander, ${ }^{17}$ Circuit Judge Treanor, in overriding the company's argument that this section of the act represented an unconstitutional delegation of legislative authority, said:18

"Section $5(e)$ of the Act prescribes a reasonably definite standard to guide the Administrator in prescribing labeling regulations. This section provides for such label regulations as will prevent deception of the consumer with respect to products or the quantity or quality thereof, and such as will prohibit, irrespective of falsity, statements likely to mislead the customer. In general, the authority of the Administrator is limited to such regulatory action, with respect to labeling, as will protect consumers from false, misleading or inaccurate representations and protect competitors from unfair trade practices in the use of labels. Decisions of the Supreme Court have upheld administrative standards which clearly are not more definite or restrictive than the one involved here" (citing cases).

In addition to providing for the issuance of labeling regulations, the act also establishes, as a means of preventing the introduction of mislabeled beverages into interstate commerce, a label approval system, and prohibits anyone subject to its provisions from domestically bottling or withdrawing from customs custody in bottles any alcoholic beverage without first applying for and securing a certificate of label approval (or, if upon application he shows that the product bottled is not to be introduced into interstate or foreign commerce, a certificate of exemption from label approval) covering the labels to be placed thereon. In the case of distilled spirits, which, under internal revenue law, may only be bottled under the supervision of government officers, those officers are directed by the statute to withhold their release from the bottling plant unless the appropriate certificates have been obtained. Similar duties are imposed upon customs officials in the case of all imported alcoholic beverages. The labeling provisions are therefore double-barreled-they not only prohibit producers, importers, and wholesalers of alcoholic beverages from introducing products into interstate commerce unless labeled in conformity with the regulations,

\footnotetext{
${ }^{17} 109$ F. (2d) 397 (C. C. A. 7th, 1940) cert. denied, 310 U. S. 646 (1940).

${ }^{18}$ See also Jameson \& Co. v. Morgenthau, 25 F. Supp. 771, at 774 (D. C. I938), decree vacated on other grounds, $3^{07}$ U. S. $17 x$ (1939).
} 
but also prohibit them from bottling or importing the same unless they have first secured the appropriate certificates evidencing the correctness of the labels. Since the passage of the act more than 495,000 applications for label approval or exemption have been acted upon. ${ }^{19}$

At first glance this system appears so watertight that no mislabeled merchandise could reach the public. There are, however, several leaks inherent in the system which it has, up to the present, been impossible to stop. The first and most serious of these results from the fact that the issuance of a certificate of approval for a label in itself furnishes no assurance that the bottler will not apply the label to products which do not conform thereto. The improper use of correct labels can only be prevented by supervision of the actual bottling operation. In the case of domestic distilled spirits, since bottling is supervised by government officers, the officer can, and does, make spot checks to be sure that the product does in fact correspond to the statements on the label, and can refer to the government records, which under internal revenue laws must be kept, and which contain all the important facts concerning the spirits being bottled. In the case of imported beverages, customs officers also make spot checks of the product and can examine the certificates of origin, age, and identity which are issued by appropriate officials of foreign governments, and which are required under the act and regulations to accompany certain imported products. Where, however, the bottling is unsupervised, as in the case of wine or malt beverages bottled by wholesalers, labels perfectly correct in themselves may be placed upon products quite dissimilar, and such a practice is usually discovered only by an examination of the product after introduction into commerce.

The second flaw results from the fact that the certificate system does not apply to retailers who can, unless prohibited by state laws, receive wine and malt beverages in bulk and bottle the same under unapproved labels.

Thirdly, in the case of malt beverages, the labeling regulations and the certificate system can, under a specific provision of the statute, ${ }^{20}$ only apply in the event the law of the state into which the malt beverages are shipped contains provisions similar to those in the federal statute and regulations.

The fourth and last leak which might permit the flow of mislabeled merchandise results from the fact that these regulations cover only such liquor as is introduced into commerce under certificates of label approval, while certificates of exemption

${ }^{19}$ F. A. A. AdMr., ANn. Reps. (1936-1939).

${ }^{20}$ This provision reads: "In the case of malt beverages, the provisions of subsections (e) and (f) shall apply to the labeling of malt beverages sold or shipped or delivered for shipment or otherwise introduced into or received in any State from any place outside thercof, or the advertising of malt beverages intended to be sold or shipped or delivered for shipment or otherwise introduced into or received in any State from any place outside thereof, only to the extent that the law of such State imposes similar requircments with respect to the labeling or advertising, as the case may be, of malt beverages not sold or shipped or delivered for shipment or otherwise introduced into or received in such State from any place outside thereof." \$5(e), Federal Alcohol Administration Act. The former Administrator repeatedly requested Congress to repeal this provision of the statute, but no action has as yet been taken, and so the labeling and advertising of malt beverages which are shipped into states that have not adopted the federal regulations remain completely unsupervised. ANN. REPs. (1936-1939). 
from label approval may be obtained to cover the labels on goods bottled for sale within the same state. This last gap has, however, been to a large extent caulked as a result of a number of measures. The issuance of certificates of exemption is conditioned upon the bottler's agreeing to state on the label that the beverages are "For intrastate sale only" (in the case of distilled spirits) or "Bottled for sale in only" (in the case of wines). ${ }^{21}$ Furthermore, distilled spirits, even when bottled for intrastate sale, must be labeled in compliance with the requirements of Regulations I3 of the Bureau of Internal Revenue and certificates of exemption for distilled spirits not conforming to these regulations are therefore denied. Moreover, it has been the practice, as a matter of cooperation with the state agencies, to return applications for such certificates for distilled spirits and wine labels from bottlers located in states which have adopted as state regulations the federal bottling requirements. ${ }^{22}$

Summarizing the administrative procedure under the certificate system, a bottler or importer of alcoholic beverages who desires to make use of a new label or change a label formerly used, forwards the same to the Government, affixed to an application for a certificate of label approval. The label and the application are carefully reviewed and, if it is found that they conform to the requirements of the regulations, a certificate of approval is then issued. If, however, the label does not meet these requirements, a certificate of disapproval is issued, bearing on its face a statement of the corrections and changes which will have to be made in the label before it can receive approval. The label may then be corrected and resubmitted for approval. The certificate of approval when obtained authorizes the release of alcoholic beverages bearing identical labels from customs or their withdrawal from the bottling plant.

The law $(\$ 5(\mathrm{e}))$ also prohibits anyone from altering, mutilating, or removing any label on alcoholic beverages introduced in interstate or foreign commerce or after shipment therein except as authorized by the Government for the purpose of complying with federal labeling requirements or with state law. This provision is necessary to prevent the application of false labels as soon as the product has crossed the state line.

Recourse to the district courts is provided for in the statute for persons who want to question the Government's action in denying applications for certificates $\left(\$_{5}(\mathrm{e})\right)$. A violation of the labeling or advertising provisions of the statute, or of regulations thereunder, may result in the suspension or revocation (if a second offense) of the permit to engage in business $(\$ \$ 4(\mathrm{~d})$ and $(\mathrm{e})$ ), or criminal proceedings involving a maximum fine of $\$ 1,000$ for each offense $(\$ 7)$.

\footnotetext{
${ }^{21}$ This requirement has been supported on the theory that the applicant's using the phrase is a reasonable step in "showing to the satisfaction of the Administrator" that the product will not enter interstate commerce. The prospective purchaser is, of course, notified by this label statement that the product is barred from interstate channels. Certificates of exemption from label approval are not issued for malt beverages in view of their peculiar status under the Act.

${ }^{22}$ The provisions of Int. Rev. Reg. 13 (supra note 13 and related text) with respect to mandatory information on labels are in all major respects the same as those of F. A. A. Reg. 5. When applications for certificates of exemption are returned because of similarity of state requirements the applicant is informed that the issuance of the certificate would serve no useful purpose and is advised to correct the label to conform to the joint federal and state requirements and obtain a certificate of label approval.
} 
The labeling and advertising regulations can, under the act, be issued only after "reasonable public notice" and "opportunity for hearing" $(\$ 5(\mathrm{e}))$. These hearings are held after notice to members of the industry, state officials and others who may be interested in the subject matter. ${ }^{23}$ In the past the hearings have been considered non-partisan and similar to legislative hearings held by congressional committees for the consideration of proposed legislation. All testimony and exhibits of a scientific or factual nature are received; witnesses are, however, not sworn and no crossexamination has been permitted, since this would unnecessarily prolong the hearing, overburden the record, and would detract from the orderly conduct of the hearing. ${ }^{24}$ Any interested party may, however, study the record and file a brief or other material of an argumentative nature in connection therewith. At the close of the hearing the record is carefully studied, summarized, and analyzed before any regulations are issued.

Three sets of regulations deal respectively with the labeling and advertising of wine, distilled spirits, and malt beverages. ${ }^{25}$ They follow the same general plan and many provisions thereof are identical. The wine and distilled spirits regulations contain elaborate and detailed standards of identity ${ }^{26}$ and not only is a product which does not conform to a standard prohibited from bearing the designation for that standard, but also all products which do conform to a standard are required to bear its designation. ${ }^{27}$ Provision is made for the designation of a product for which no standard is prescribed, in accordance with the trade understanding thereof, if any, or by a distinctive and fanciful name with a statement as to its composition.

In general, the regulations require labels to bear the brand name of the product, the class and type thereof, the name and address of the producer, importer, or bottler, the alcoholic content (except in the case of certain wines and malt beverages), and the net contents. ${ }^{28}$ In the case of blends of foreign and domestic wines where the label refers to the foreign wine, the exact percentage thereof must also be stated; ${ }^{20}$

\footnotetext{
${ }^{23}$ The notices of hearing contained either a form of proposed regulation or a short summary of the proposal to be considered. The hearings on the original regulations were held as follows-on the proposed wine regulations, Nov. 22, 1935; on the proposed distilled spirits regulations, Oct. 31, 1935; on the proposed malt beverage regulations, Jan. 7, 1936. Since the promulgation of these regulations, the $\Lambda \mathrm{d}$ ministration has held a number of public hearings to consider proposed amendments to the regulations.

24 At the hearing held April 27, 1939, to consider a number of proposed amendments to the distilled spirits labeling and advertising regulations, representatives of the Distilled Spirits Institute and the National Association of Alcoholic Beverage Importers, Inc., strongly urged that witnesses be sworn and that crossexamination be allowed. The Administrator denied these requests but permitted the submission of written questions which he himself asked if he considered them appropriate. He took the position that questions relating to the conduct of the hearing were properly matters resting on his own discretion.

${ }^{25}$ F. A. A., Regs. 4 (Relating to Labeling and Advertising of Wine), 5 (Relating to Labeling and Advertising of Distilled Spirits), and 7 (Relating to Labeling and Advertising of Malt Bcveragcs). 27 CODE FEd. REg., pts. 4, 5, 7. Although the Federal Alcohol Administration was abolished under the President's Third Reorganization Plan, issued pursuant to the Reorganization Act of 1939, 53 STAT. 56I, 5 U. S. C. \$133 (Supp. V 1940), the functions of the Administrator were transferred to the Alcohol Tax Unit of the Bureau of Internal Revenue and the regulations issued by the Administration remained in effect. TD-4974, June 12,1940 , effective June 30 , 1940 .
${ }^{26}$ F. A. A. Regs. 4, art. II; 5, art. II.
${ }^{28} \mathrm{Id}$. 4, art. III, $\$ \$ 32-37 ; 5$, art. III, $\$ \$ 32-39 ; 7$, art. II, $\$ \$ 22-27$.

${ }^{20} I d$. 4, art. III, $\$ 32(\mathrm{a})(4)$.
} 
and, in the case of distilled spirits, the presence of artificial or excessive coloring or flavoring material, the percentage of neutral spirits and the source thereof, the age of the whisky, and the state of distillation (except in certain instances) must appear. ${ }^{30}$ The manner in which such statements shall be made and the place where they shall appear (whether on the main label or on a separate label) is set forth in detail, even in some cases to the extent of prescribing the exact form of the statement. ${ }^{31}$ The regulations contain elaborate provisions for the protection of geographical designations and establish certain names which have become generic, others which may be used if the actual place of production is stated, and still others which may oniy be used if the product was in fact produced in the place indicated by the geographical name. ${ }^{32}$ In the case of imported distilled spirits certain representations may only appear if supported by certificates issued by authorized officials of the appropriate foreign government. ${ }^{33}$

So much for the information which is required to appear upon labels. The regulations also contain detailed provisions prohibiting certain material from appearing upon labels, including statements which are false or untrue or which by ambiguity, omission, or inference tend to create a misleading impression, disparaging statements, obscene or indecent statements, misleading statements with respect to guaranties, the use of names which would falsely indicate endorsement or sponsorship, any simulation of government stamps, or indication of government approval, statements relating to analyses, standards or tests which might mislead the consumer, or statements with respect to curative or therapeutic effects. ${ }^{34}$ In addition to the above, the respective regulations contain other provisions prohibiting practices which are applicable to the particular products covered. ${ }^{35}$ The regulations also establish procedure for the withdrawal of imported alcoholic beverages from customs custody and for the bottling and withdrawal of domestic alcoholic beverages. ${ }^{36}$

The advertising requirements are in general less detailed; $; 7$ for instance, only the name of the responsible advertiser, the class and type, the alcoholic content (except in the case of certain wines and malt beverages), and, in the case of distilled spirits, the percentage and source of neutral spirits used, are required to appear. ${ }^{38}$

${ }^{30} I d .5$, art. III, $\$ \$ 32,34(\mathrm{c}), 35(\mathrm{~g}), 38,39$.

${ }^{31}$ E.g., see $i d .5$, art. III, $\$ 39$, which sets forth the exact form of age statement which must be used upon labels of various types of whisky.

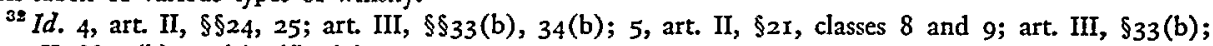
7, art. If, $\$ \$ 23(\mathrm{~b}), 24(\mathrm{e}),(\mathrm{f}),(\mathrm{g})$.

${ }^{33}$ Id. 5, art. III, $\$ 4 \mathrm{r}(\mathrm{b})(\mathrm{z})$; art. IV, $\$ 46$; art. V, $\S_{5 \mathrm{I}}$.

${ }^{34} I d .4$, art. III, \$39; 5 , art. III, $\$ 41 ; 7$, art. II, \$29.

${ }^{36}$ E.g., the wine regulations prohibit age statements other than vintage and bottling dates under certain circumstances. F. A. A. Regs. 4 , art. III, $\$ 39$ (b), (c), (d), (c). The distilled spirits regulations limit the use of the words "bottled in bond," etc., the word "pure," and the words "double distilled." Id. 5, art. III, $\S_{4} \mathrm{I}(\mathrm{b})(3)$ and (4), (c), (d). The malt beverage regulations prohibit the use of numerals likely to be considered as alcoholic content statements, and words such as "strong," "full strength," and the words "bonded," "bottled in bond," etc. Id. 7, art. II, \$29(c), (f), (g).

${ }^{30} 1 d$. 4 , arts. IV, V; 5, arts. IV, V; 7, arts. III, IV.

${ }^{37} \mathrm{Id}$. 4 , art. VI; 5, art. VI; 7 , art. V.

${ }^{38} I d .4$, art. VI, $\$ 62 ; 5$, art. VI, $\$ 62 ; 7$, art. V, $\$ 52$. 
The provisions with respect to prohibited statements are similar to those applicable to labeling, ${ }^{39}$ with the added requirement that no statements may appear in advertisements which are inconsistent with statements appearing upon the label of the product, ${ }^{40}$ and the further requirement, in certain cases, that if a statement is made in the advertisement, it shall appear in the form in which it is required to appear upon the label. ${ }^{41}$ Although the distilled spirits regulations establish standards of fill for containers for such products, ${ }^{42}$ standards of fill have not as yet been prescribed for wines and malt beverages.

With respect to advertising, the statute prohibits producers, importers, and wholesalers of alcoholic beverages from publishing any advertisement of alcoholic beverages by radio broadcast, in newspapers, periodicals, etc., or by signs or outdoor advertisements, or other printed or graphic matter which are not in conformity with the regulations. ${ }^{43}$ The act covers not only such advertisements as are themselves in interstate or foreign commerce, but also includes all advertisements disseminated by mail and all advertisements which are calculated to induce sales in interstate or foreign commerce. Thus, it includes within the scope of the provisions outdoor signs or other advertising media fixed to a particular location whenever such media are used to invite the shipment of alcoholic beverages in interstate commerce. The legislative standards for the regulations are substantially the same as those prescribed for the labeling regulations, with the exception that they do not apply to outdoor advertising in place on June $18, x 935$, when the industry was notified of the contemplated restriction on advertising material by the introduction of the bill in Congress. ${ }^{44}$

The statute establishes no procedure, similar to the label certificate system, requiring the submission of advertising material for approval in advance of publication. It has, however, been the past practice, as a policy matter, to review and comment informally upon proposed advertising material upon request. This has operated to correct in advance of publication a tremendous number of advertising campaigns, as well as individual advertisements, which would, if published, have resulted in a violation of the regulations. ${ }^{45}$ These comments are, of course, as above stated, informal and are not considered to be binding upon the industry or the Government. In the event that the industry member does not agree with the position taken by the Government with respect to proposed material, he may, of course, publish the proposed material, without prejudice, and the correctness of the Government's position can then be tested in the manner provided by the statute. ${ }^{40}$

${ }^{39} \mathrm{Id}$. 4, art. VI, $\$ 6_{4} ; 5$, art. VI, $\S 64 ; 7$, art. V, $\$ 54$.

${ }^{10} I d$. 4, art. VI, $\$ 64(\mathrm{~b}) ; 5$, art. VI, $\$ 64(\mathrm{~b}) ; 7$, art. V, $\$ 54(\mathrm{~b})$.

"1 E.g., the distilled spirits regulations prevent any reference to age in advertisements unless a statement of age appears upon the label of the product and unless the representation in the advertisement includes all parts of the labeling age statement (Regs. 5, art. VI, $\$ 6_{4}(\mathrm{c})$ )).

${ }^{4} I d .5$, art. VII. ${ }^{43} 85(f)$.

79 Cong. Rec. 12267 (1935).

${ }^{46}$ During the calendar year 1939 approximately 2,835 proposed advertisements were reviewed by the Federal Alcohol Administration prior to publication and approximately 1,109 conferences held at the request of industry members, advertising agencies, etc. F. A. A. ADMr. ANn. Rep. (1939).

${ }^{46}$ I.e., by the institution of permit suspension proceedings, or of criminal prosecution, or of suit to restrain the violation. $\$ \$_{4}(\mathrm{e}), 7$. 
Advertising material appearing in newspapers, periodicals, and other publications is closely checked; in addition, radio scripts, recipe booklets, and other advertising material are reviewed whenever there is any question as to their validity. ${ }^{47}$ The same penalties result from a violation of the advertising regulations as are provided in the case of labeling violations.

The industry and others interested were kept advised of the Administration's views on new practices in the trade and of its current interpretations of the statute and regulations by the issuance of circular letters covering separate interpretations or rulings in individual cases involving questions of general interest, and in the case of distilled spirits, digests or summaries of such interpretations. ${ }^{48}$ In addition, the former Administrator attempted, through the cooperation of the industry, to discourage certain practices in advertising alcoholic beverages which were believed socially objectionable, for example, the use of Sunday newspapers as advertising media, the use of pictures of women, children, or religious objects or insignia, and references to tonic or food qualities. ${ }^{49}$

So much for the control of alcoholic beverage labeling and advertising under the Federal Alcohol Administration Act. As indicated above, the jurisdiction of the Federal Trade Commission and of the Food and Drug Administration extend into this field under their more general powers. These agencies have, however, since the passage of the Federal Alcohol Administration Act, limited their exercise of this jurisdiction to cases which were not covered by the Federal Alcohol Administration Act, referring cases in which there is concurrent jurisdiction for treatment under the more specific statute. ${ }^{50}$

Turning to the Federal Trade Commission Act, Section 5 declares unfair methods of competition in commerce to be unlawful and authorizes the Commission to prevent anyone from using such methods. ${ }^{51}$ The Commission is authorized to proceed against violators by complaint and cease and desist order. It was formerly necessary for the Commission not only to prove that a particular practice was unfair and that a proceeding was to the interest of the public, but also that the practice was engaged

\footnotetext{
${ }^{47}$ F. A. A. ADMr. ANn. REP. (1939) contains the statement that all alcoholic beverage advertisements appearing in 26 newspapers and 40 magazines were regularly reviewed, in addition to the review of all such advertisements appearing in 60 different daily newspapers in varying localities. It also states that 67,162 newspaper and magazine advertisements and 6,970 advertisements in the form of booklets, leaflets, posters, etc., have been examined during the past year. This statement did not include the monthly review of approximately 425 commercial radio broadcasts.

${ }^{48}$ These circulars bore the symbol FA and were, as indicated, of an explanatory or an informative nature. The summaries referred to were FA-9I, Jan. 21, 1937 and FA-123, Oct. 15, 1937.

10 The former Administrator of the F. A. A. urged the elimination of these practices in several specches before meetings of members of the industry or of the various state liquor agencies. It was also recommended in the annual reports that Congress prohibit these practices by legislation.

"This "informal collaboration" between the F. A. A. and the F. T. C. is referred to in the monograph, Atty. Gen's. Com. on Adm. Proc., The Federal Trade Commission (i940) note 22.

51 "Section 5. (a) Unfair methods of competition in commerce, and unfair or deceptive acts or practices in commerce, are hereby declared unlawful.

"The Commission is hereby empowered and directed to prevent persons . . . from using unfair methods of competition in commerce and unfair or deceptive acts or practices in commerce." 38 STAT. 719 (1914) as amended by 52 STAT. III and I028 (1938), 15 U. S. C. $\$ 45$ (Supp. IV 1938).
} 
in in competition and resulted in an injury to competitors. Thus, the protection of consumers was necessarily incidental to the protection of competitors. The $193^{8}$ amendments to the act added to the phrase "unfair methods of competition," "unfair or deceptive acts or practices." This latter phrase does not add anything to the type of case over which the Commission formerly had jurisdiction, but makes it unnecessary for the Commission to show in each case any injury to respondent's competitors. ${ }^{52}$

In I929 the Commission determined to give special treatment to misrepresentations occurring as the result of false and misleading advertising, and since that time it has reviewed newspaper and magazine advertising and, since 1934, radio advertising. ${ }^{53}$ The Commission can, however, deal only with individual cases as they arise in commerce and is neither entitled to formulate general rules for the control of advertising nor to require that mandatory information be contained in advertising material. The $193^{8}$ amendments to the act do not change this situation. ${ }^{64}$

The cases which the Federal Trade Commission has undertaken in the liquor field involve roughly four general types of representations: (I) representing a product to be something which it is not; 5 (2) false representations that the product has a certain geographical origin; ${ }^{56}$ (3) representations that a product has been made by a

52 The purposes of these amendments are summarized in the report of the Committe on Intcrstate and Foreign Commerce of the House of Representatives: "To summarize, this legislation is needed to give the Federal Trade Commission jurisdiction over unfair acts and practices for consumer protection; to relieve the Government of unnecessary time and expense in proving an injury to a compctitor as a prerequisite to consumer protection and to the suppression of an unfair method in commerce, and to give more effective and necessary control over false advertisements of food, drugs, devices, and cosmetics.

"The legislation seeks to establish no new bureaus or to take on new fields of activity, but rather to provide more effective methods of accomplishing that, which broadly speaking, are the purposes of the existing law." H. R. REP. No. 1613 , 75th Cong., Ist Sess. (1937) 9. The following excerpts from the report indicate Congressional intention to change the base of the statute from competition to consumer protection: "The words 'unfair method of competition' in section 5 have been construed by the Supreme Court as leaving the Commission without jurisdiction to issue cease and desist orders where the Commission has failed to establish the existence of competition. In other words, the act is construed as if its purpose were to protect competitors only and to afford no protection to the consumer without showing injury to a competitor. . . . By the proposed amendment to section 5 , the Commission can prevent such acts or practices which injuriously affect the general public as wcll as those which are unfair to competitors. In other words, this amendment makes the consumer, who may be injured by an unfair trade practice, of equal concern, before the law, with the merchant or manufacturer injured by the unfair methods of a dishonest competitor." Id. 3 .

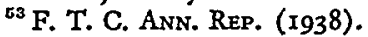

st "It will be observed that it is not mandatory on the advertiser to state anything. The only requirement is in case he does advertise, he shall not make statements that are misleading in a material respect. It is incumbent on the advertiser to reveal facts material in the light of representations made in the advertisement." H. R. REP. No. 1613, 75th Cong., Ist Sess. (1937) 5.

${ }^{55}$ E.g., F. T. C. Stipulations Nos. 1315, 1316, 1396, 1398, 1412, and 1472 corrected a misuse of the designation "Champagne"; No. 1398 prevented the use of the term "Sparkling Burgundy" on a certain product unless accompanied by the word "carbonated"; Nos. 1387 and 1547 corrected representations that whiskies were "Scotch," "bottled in bond," or "made from finest American grain"; sce also Stipulation No. 232 and cease and desist orders on Complaints Nos. 2803 and 2949.

${ }^{60}$ E.g., Stipulations Nos. 949, 956, 1055, 1310, and 1325 corrected the misuse of the geographical names "St. Thomas" and "West Indies" in connection with rum not produced in those localities; No. 2510 discontinued the use of the words "Cervesa-exquisita Chapultepec" on beer not made in Mexico and imported into this country. See also Stipulation No. 2108, and a cease and desist order on Complaint No. 2849 , which ordered a company to discontinue representing that its whisky was distilled in Scotland or 
certain process or under certain sponsorship; 57 (4) false representations as to the trade status of the producer or vendor. ${ }^{58}$

The $193^{8}$ amendments to the Federal Trade Commission Act contained specific provisions with respect to the dissemination of false advertisements of foods (the definition of food is broad enough to include alcoholic beverages), drugs, devices, or cosmetics, by mail or in interstate commerce, and made such dissemination an unfair or deceptive practice under Section $5 .^{59}$ It also gave the Commission power, under certain circumstances, to bring suit to enjoin the dissemination of such an advertisement, ${ }^{60}$ and made it no longer necessary for the Commission to prove that the advertisement was disseminated with a fraudulent intent. ${ }^{61}$

It should, however, be noted that the only remedies offered by the act consist in the issuance of a cease and desist order or injunction proceedings which usually would occur after the advertisement has been presented to the public, and that there is no effective punishment for the dissemination of a false liquor advertisement other than the mere discontinuance of its use. Moreover, the act does not provide for any correlation between the advertising of a product and the labeling thereof, nor require that information concerning products advertised be furnished to the public. All of

that the bottler distilled it or operated a distillery when the whisky was in fact distilled and bottled by another company outside of Scotland.

${ }^{67}$ E.g., F. T. C. Stipulation No. 1288 discontinued the designation of a beer as "Krausened" when it was not carbonized with its own natural gas; No. 1948 discontinued representations that lager beer is dependent on lengthy aging, that the company's storage capacity was the largest in the West, and that it has brewed ale and stout since 1878 , when untrue. Complaint No. 2888 was dismissed when four brewing companies agreed by stipulation to discontinue representing that their products contained no carbohydrates or fat-producing properties, that a special non-fattening formula produced a slenderizing effect on people of excess weight; the beer could, however, be represented as "dietetically nonfattening." See also cease and desist order on Complaint No. 2819. Stipulation No. 2037 corrected the false statement that a certain rum produced in the Virgin Islands was distilled, aged, or bottled under U. S. Government supervision; see also Stipulation No. 2460 .

ES This type of case is by far the most common. In approximately 100 instances the Commission has by cease and desist orders or stipulations forced the discontinuance of false representations that a company operated a distillery, or distilled its products. Usually these representations included the use of the words "distiller," "distillery," "distillers," "distilling company," etc., in or in connection with the corporate name. The fact that in preventing this comparatively simple practice it has been necessary to institute over 100 separate proceedings in the past and will be necessary to institute new proceedings in the future whenever it is indulged in, indicates the greater efficiency and economy resulting from prohibiting such practices by the issuance of regulations.

${ }^{10} 52$ STAT. II4 (1938), I5 U. S. C. \$52. (Supp. IV, 1938). "Section 12 (a). It shall be unlawful for any person, partnership, or corporation to disseminate, or cause" to be disseminated, any false advertisement-( $\mathrm{x}$ ) by United States mails, or in commerce by any means, for the purpose of inducing, or which is likely to induce, directly or indirectly, the purchase of food, drugs, devices, or cosmetics; or (2) by any means for the purpose of inducing, or which is likely to induce, directly or indirectly, the purchase in commerce of food, drugs, devices, or cosmetics.

"(b). The dissemination or causing to be disseminated of any false advertisement within the provisions of subsection (a) of this section shall be an unfair or deceptive act or practice in commerce within the meaning of section 5." ${ }^{00} 15$ U. S. C. $\$ 53$ (Supp. IV, I938).

${ }^{02}$ The House Committee report states: "A. false advertisement is defined as one "which is misleading in a material respect.' Certain specified matters are to be considered in determining whether or not an advertisement is misleading. This definition is very broad. It will be noted that a fraudulent intent is not a necessary element of a false advertisement. The essential elements of a false advertisement are that it is mislcading, and misleading in a material respect. . ." H. R. Rep. No. 1613, 75th Cong., rst Sess. (I937) 5. 
these elements are particularly important in connection with alcoholic beverage advertising.

The Federal Food and Drug Act of 1906 prohibited anyone from shipping or receiving in interstate commerce any adulterated or misbranded food or drugs on penalty of a fine or imprisonment or both. The definition of the term "food" contained in the statute was sufficiently broad to cover all alcoholic beverages. ${ }^{02}$ In addition to the criminal penalties, the Act provided for the seizure and confiscation of misbranded or adulterated articles and prohibited the importation of articles which were prohibited or restricted in the country from which exported.

Section 3 of the statute authorized the Secretary of the Treasury, the Secretary of Agriculture, and the Secretary of Commerce to make uniform rules and regulations. Although no comprehensive liquor regulations were issued under the statute, standards for wine, dry wine, fortified dry wine, sweet wine, and fortified sweet wine were adopted, ${ }^{63}$ and a few decisions with respect to the labeling of alcoholic beverages were issued under the act or general regulations. ${ }^{64}$ These various decisions constituted an important foundation for the building of the Federal Alcohol Control Administration's regulations. They were extremely important in establishing customary trade practices and as indicative of types of earlier misbranding practices and of possible corrective measures.

After a long and perilous gestation in Congress, the new Food, Drug and Cos-

${ }^{02} 34$ STAT. 768 (Ig06); 2 I U. S. C. c. I. The definition of "drug" is also broad cnough to cover such alcoholic beverages as are also defined in the U. S. Pharmacopoera and National Formulanx. In view of the fact that this article is concerned with alcoholic beverages as such, controls over the labeling and advertising of alcoholic beverages for medicinal use are not within its scope. $\$ 8$ of the statute provided roughly that an article was misbranded ( $r$ ) if labeled with any statement, design, or device which is false or misleading in any particular, or (2) if misbranded as to the state or country of production, or (3) if an imitation of or sold under the name of another article, or (4) if labeled so as to deceive or mislead the purchaser, or (5) if it purports to be a foreign product when not so, or (6) if substitution shall have been made for its original contents, or $(7)$ if not labeled with the quantity of any of certain named drugs, or (8) if not labeled with the contents in terms of weight, measurc, or numerical count (with certain exemptions), or (9) if labeled with any false or misleading statement, design, or device, regarding its ingredients or contents.

${ }^{63}$ U. S. Dept. Agriculture, Definitions and Standards for Food Products, Service and Regulatory Announcements, Food and Drug No. 2, 4th Revision, Aug., 1933.

${ }^{64}$ The most important of these was Food Inspection Decision 113 , Feb. 16, 1910, which was issucd to carry into effect President Taft's decision in the whisky controversy, supra note 3, and specified instances in which whisky would have to be labeled "blended," "compound," or "imitation." Sce also F. I. D. 125, July 30, 1910; F. I. D. 141, Feb. 17, 1912; F. I. D. 156, June 12, 1914; F. I. D. 152, Sept. 3, I913; F. I. D. 122, June 20, 1910; F. I. D. 127, Oct. 19, I910; F. I. D. 85, Fcb. 3, 1908.

Certain of the Service and Regulatory Announcements of the Bur. of Chemistry of the Dept. of Agriculture related to the labeling of alcoholic beverages, notably S. R. A. Chem. 3, item 25, May 12, Igr4, as amended, by S. R. A. Chem. 7, item 67, Aug. 25, I914; S. R. A. Chem. I6, itcm 158, Jan. 26, 1916; S. R. A. Chem. 21, item 242, Nov. 12, 1917; S. R. A. Chem. 3, item 30, May 12, 1914; S. R. A. Chem. 22, item 267, April 8, 1918; S. R. A. Chem. 17, item 175, May 12, 1916; S. R. A. Chem. I6, item I60, Jan. 26, I916 (holding that Scotch whisky must be manufactured in Scotland); S. R. A. Chem. 3, item 26, May 12, 1914 (providing that California brandy having the characteristics of Cognac and similarly produced may be labeled "Brandy-Cognac type" if the state of production is also stated); S. R. A. Chem. 20, item 224, July 2, 1917; S. R. A. Chem. 17, item 174, May 12, 1916; and S. R. A. Chem. 20, item 223, July 2, x917; S. R. A. Chem. 19, item 204, March 12, 1917, and S. R. A. Chem 20 , item 227 , July 2, 1917, requiring that spirits imported from Great Britain bc accompanied by a certificate from the British Government to the effect that they are suitable for home consumption in view of the requirements of the BRITISH IMMature SPIRTTS Act that spirits for home consumption be warehoused for at least three years. 
metic Act came into being on June 25, $1938{ }^{65}$ Among other things this act greatly increased the Government's powers over the labeling of food, not alone prohibiting the adulteration and misbranding of foods in interstate commerce and the shipment or receipt of such foods ( $\$ 30 \mathrm{O}(\mathrm{a})$, (b), and (c)), but also the alteration, mutilation, destruction, obliteration, or removal of the whole or any part of the labeling of, or the doing of any act to, an article of food held for sale after shipment in interstate commerce which results in the article being misbranded $(\$ 30 \mathrm{~K}(\mathrm{k})$ ). Provision is made for injunction proceedings to restrain violations and for additional and more stringent penalties ( $\$ \$ 302$ and 303 ).

Perhaps the greatest advance in the control of labeling may be found in Section 40I, which authorizes the promulgation of regulations fixing "reasonable" definitions and standards of identity, standards of quality, and standards of fill which will "promote honesty and fair dealing in the interest of consumers." As in the case of the I938 amendments to the Federal Trade Commission Act, the protection of the consumer has become paramount. Provision is also made for the serving of notices and the holding of public hearings in connection with such regulations ( $\$ 70 \mathrm{r}(\mathrm{e})$ ).

The term "misbranding" is for the first time given the specific interpretation of including a consideration, not only of representations appearing upon the label, but also of whether material facts are omitted with respect to the consequences which may result from the use of the article under the conditions prescribed on the label or under customary or usual conditions. Moreover, the definition of misbranding foods has been broadened and made much more definite. Roughly paraphrased, Section 403 of the act provides that a food is deemed misbranded (a) if its labeling is false or misleading in any particular, (b) if offered for sale under the name of another food, (c) if an imitation of another food unless the name of such food appears followed by the word "imitation," (d) if its container is so made, formed, or filled as to be misleading, (e) if packaged, unless labeled with the name and address of the manufacturer, packer, or distributor, and the net contents (subject to exemptions), ( $f$ ) if any statement required by the Act or regulations to appear does not appear conspicuously, (g) if purported to be a food for which a standard has been prescribed unless it conforms to the standard and bears the name of such food and the names of optional ingredients if required, $(h)$ if it purports to be a food for which a standard of quality or of fill has been prescribed and it falls below such standard unless it bears a statement to this effect, (i) if not subject to (g), unless it is labeled with the common or usual name of the food and, if made of two or more ingredients, the common or usual name of each such ingredient (with certain exceptions), (j) if it purports to have a special dietary use unless labeled with such information concerning its dietary properties as may be prescribed by regulations in "order fully to inform purchasers as to its value for such uses," (k) if it contains any artificial flavoring or coloring or any chemical preservatives unless labeled with this fact (subject to exemptions). No standards for alcoholic beverages have been

\footnotetext{
${ }^{05} 52$ Stat. 1040 (1938), 2 I U. S. C., c. 9 (Supp. IV, 1938). See The New Food, Drug and Cosmetic Legislation (1939) $6 \mathrm{LAw} \&$ ConT. Prob. No. I (entire issue).
} 
prescribed under the act, although it is broad enough to authorize the promulgation of such standards. ${ }^{66}$ Moreover, as a matter of practice all matters relating to the labeling of alcoholic beverages are, if covered by the Federal Alcohol Administration Act, referred for treatment under the more specific statute.

The federal power to control advertising and labeling of alcoholic beverages in the interstate field is complemented by the powers of the several states to control these practices within their own borders and, under the Twenty-first Amendment, to prohibit the entry of beverages which fail to comply with their several requirements. In the large majority of the states the liquor control agency is specifically empowered to prescribe labeling regulations; ${ }^{67}$ the broad power to prescribe advertising regulations has, however, not been so generally bestowed.8 ${ }^{88}$ In a few of the states, the liquor statutes themseves contain labeling or advertising requirements ${ }^{30}$ or even standards for certain beverages commonly produced therein ${ }^{70}$ or prohibit the use of certain advertising media for alcoholic beverages. ${ }^{71}$

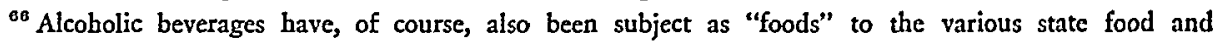
drug acts which are, in the main, similar to the federal act of 1906.

${ }^{\circ 7}$ Ala., Calif. (Bureau of Food and Drug Inspection), Conn., Del., Fla., Ga., Idaho, Ill., Ind., Iowa, Ky., Md., Mass., Mich., Minn., Mo., Mont., Neb., N. H., N. J., N. Y., N. C., N. D. (Food Commissioner), Ohio, Ore., Pa., S. C., S. D., Tenn., Tex., Vt., Va., Wash., W. Va. and Wis. This does not include states which have the general power to issue regulations to administer the provisions of the scveral liquor control acts.

${ }^{88}$ Conn., Ga., Ind., Iowa, Ky., Md., Minn., Mont., Neb., N. H., N. C., Ohio, Orc., S. D., Tenn., $T e x$., $V t$. and $W$. Va. Many other state agencies have issued advertising regulations under general statutory powers to promulgate regulations to administer the liquor statutes and control the traffic in alcoholic beverages.

${ }^{60}$ E.g., art. VI, $§ 6$, of the ILL. Liquor Control Acr, as amended (43 ILL. STAT. (Smith-Hurd, Supp. 1939-40) 124), provides that labels on alcoholic beverages must bear the name and address of the manufacturer, the kind of liquor, the date of manufacture (except beer and 4-year-old Scotch whiskicy and brandy), and the minimum alcoholic content. Similar provisions are found in the Maine, Mont., Neb., Okla. (beer), Pa., Tex. (beer), Utah (beer) and Wash. laws. State statutes also frequently prohibit representations that beer is "strong," "high-test," "pre-war strength" and similar representations of alcoholic content (Ky., Miss., Okla., and Pa.); other state statutes prohibit the use of the word "bar" or "saloon" on signs (Calif., Iowa, Mont., Wis.). There is, however, little uniformity of statutory provisions with respect to labeling and advertising. They run all the way from an isolated provision in the Michigan statutes (Mrch. Comp. Laws (Mason's 1935 Supp.), §17115-42) which makes it a misdemeanor to post or distribute any advertisement for intoxicating liquor containing any rcfercnce to any deceased ex-President of the U. S. A. to a law in Vermont (Pub. Laws 1933, \$8647), prohibiting liquor advertising within 200 feet of a church. In some states the size and contents of outside signs has been made a subject of statutory control (Idaho, Calif., Me.). In general, however, it may be said that where the state law provides for an exercise of any broad control in the advertising and labeling field, it does so by authorizing an agency to promulgate regulations filling in the details of control.

${ }^{70}$ E.g., the ILL. Liquor Control ACT, supra note 69, provides that no product may be labeled "gin" or "whiskey" unless its entire alcoholic content is derived from grain; otherwise it must be labeled "imitation." Kentucky has gone ever farther and has established a standard and immature spirits control for whiskies bearing the name "Kentucky." Carroll's Kr. Stats. (Baldwin's 1936 revision, 1939 Supp.) $\$ 2554 \mathrm{~b}-169$.

${ }^{71}$ For instance the Alabama statute provides that liquor advertising may only be carried in newspapers, magazines, or or the radio except in the case of wine and beer, which may also appcar on billboards. The Arkansas statute provides that in no event shall liquor advertising be prohibited in newspapers; in Delaware poster boards and painted bulletins are permitted for wine and becr in Wilmington, and newspaper, periodical and radio advertising is expressly permitted. In Kentucky it is unlawful to distribute handbills or posters in dry territory and the power to regulate advertisements in newspapers, magazines, or periodicals is expressly reserved by the statute. In Mississippi all advertising of alcoholic beverages is prohibited except in the case of beer and light wines; in Montana illuminated signs are prohibited; in New Hampshire all advertising of liquor except in newspapers, magazines, periodicals and over the radio is prohibited unless authorized by the Commission; in North Carolina advertising 
The chaotic situation which would result if varying regulations with respect to labeling and advertising were issued by each state agency as well as by the Federal Government early became apparent ${ }^{72}$ and, in order to avoid economic waste, to facilitate administration, and to provide consumers with the same protection when buying intrastate products that they receive in the case of interstate products, the Federal Alcohol Administration consistently urged that its labeling and advertising regulations be adopted by the various states as minimum requirements. ${ }^{73}$ This effort has received the hearty support of the industry, since it eliminates much of the difficulty and expense involved in advertising and distributing their products throughout the country. It has, moreover, been promoted by the Council of State Governments ${ }^{74}$ and by the two associations composed respectively of state liquor administrators for the monopoly and for the license states ${ }^{75}$ and proposed uniform bills have been drafted $^{70}$ for submission to the state legislatures.

The fact that, in several state laws, the power delegated to the state agency to issue its own regulations contains a specific reference to the federal regulations and in a few instances actually incorporates them by reference indicates that the desirability for uniformity in labeling and advertising control is recognized by the state legislators themselves. ${ }^{77}$

The views of state officials have been requested at all of the public hearings held for the consideration of federal regulations, and several conferences have been held

alcoholic liquors on billboards along public highways or streets is prohibited by statute; in Utah the statute prohibits electric or illuminated signs, signboards, billboards, display signs and advertising pieces except in the case of light wines; in Idaho and Iowa advertising of alcoholic liquors is prohibited except as permitted by federal statute and regulations. Limitation of space prohibits any discussion in this article of the many provisions with respect, to advertising requirements of the regulations of the various state liquor control agencies.

${ }^{2}$ The report of the 1935 Committce on Uniform Laws of the National Conference of State Liquor Administrators recommended the adoption of uniform labeling regulations based upon those of the F. A. A. This report was approved as the sense of the conference at its annual meeting in December of 1936 .

${ }_{73}$ The former Administrator repeatedly recommended the adoption of uniform state labeling and advertising regulations in various addresses before meetings of industry trade associations and of state liquor control officials during 1936 -r 939 .

" Uniform labeling and advertising based upon the F. A. A.'s regulations was endorsed at the Regional Liquor Control Conference, sponsored by the Council of State Governments in New York, Dec. 19, 1936, and Nov. I8, 1938, and in Buffalo, N. Y., Jan. 5, 1940.

${ }^{75}$ Resolutions with respect to the adoption of federal labeling regulations were adopted at the Conference of Liquor and Beer Administrators in Des Moines, Iowa, in Dec. 1936 and at the National Conference of State Liquor Administrators, St. Paul, Minn., June 15, 1938 (uniform advertising regulations).

${ }^{70}$ These bills were drafted to authorize the adoption by the state liquor control agency of regulations restricting advertising which "shall, as far as possible, be in the interest of a minimum uniform national standard," and in the case of labels which should "be calculated to prohibit the deception of the consumer; to afford him adequate information as to quality and identity; and to achieve national uniformity in this field in so far as possible" (Legislative Proposals Nos. I and 5, presented at the 4th General Assembly of the Council of State Governments, held in Washington, D. C., Jan. 18, 1939, and presented at various regional conferences on liquor control sponsored by the Committee on Interstate Cooperation of the Council of State Governments).

${ }^{77}$ In Ga., Ky., N. C. and S. C. certain of the federal regulations have been incorporated by reference into the state liquor law itself. This procedure was followed in N. M. but the provision was repealed after its constitutionality had been questioned. In other states it is provided that the regulations shall be "not inconsistent with" (Ga., Neb. and S. D.), "similar to" (Md.), "which shall comply with" (Fla.), "not in conflict with" (Ohio), "in strict accordance with" (Tex.), or "to adopt" (Ky., Vt. and Tenn.) the F. A. A.'s regulations specifically or federal requirements generally. 
for the discussion of labeling and advertising problems. The most important of these took place on October 25, I938, as a result of resolutions passed at the annual meetings of the two state liquor control groups, and resulted in the forwarding to each state agency of a questionnaire to ascertain its reaction to the myriad questions involved in the control of liquor advertising. ${ }^{78}$

To date, 32 states have adopted the Administration's regulations in whole or in part. ${ }^{79}$ In the case of such states, as noted above, the Federal Alcohol Administration discontinued the issuance of certificates of exemption from label approval, and, when requested, forwarded copies of all letters with respect to advertising in such state to the state agency. By this means a high degree of uniformity of control has been attained, even though the state may impose additional and more detailed requirements of its own. ${ }^{80}$ In this field, too, however, the situation with respect to malt beverages is more complicated than that of distilled spirits and wine, in view of the fact that in several states the regulation of such beverages is not included in the liquor control act but in separate legislation frequently of a revenue rather than a social nature. ${ }^{81}$ The adoption of the federal regulations has been accomplished either by a regulation incorporating the federal requirements by reference or by reissuing as state regulations the separate requirements of the federal regulations. ${ }^{82}$

In addition to the existing federal and state controls over alcoholic beverage labeling and advertising, some reference should be made to legislation now pending before Congress which, if passed, will affect this subject. In his annual reports to Congress for the years 1937, 1938, and 1939, the Administrator of the Federal Alcohol Administration recommended that Congress amend that act to prohibit the advertising of alcoholic beverages over the radio. ${ }^{83}$ Although the action of the Distilled Spirits Institute in declaring itself opposed to the use of this advertising medium for distilled spirits and of the National Association of Broadcasters in adopting a resolu-

${ }^{78}$ The replies to this questionnaire indicated that, out of 17 state agcneies, I4 desircd uniformity of state advertising regulations, I was opposed, and 2 believed it would be impracticable; 13 state agencies expressed themselves in favor of further affirmative action to attain uniformity. The replics to the questionnaire upon the detailed questions with respect to the use of various advertising media and the prohibition or regulation of many forms of representations in liquor advertising indicated, however, that wide divergence of opinion which is reflected in the present state regulations.

${ }^{70}$ Ten states have adopted the labeling and advertising requirements for wine, distilled spirits and malt beverages (Ariz., Mo., Me., Mont., S. C., Texas, Tenn, Utah, Va., and W. Va.); 4 morc states have adopted the labeling and advertising requirements for wine and distilled spirits (Idaho, Minn., N. C., and Pa.); Ga. and Ohio have adopted both labeling and advertising requirements for wine and Ga. has also adopted the labeling requirements for distilled spirits; ro states have adopted the labeling regulations for all alcoholic beverages but have not adopted the advertising requirements (Del., Ill., Ky., Neb., N. J., N. Y., Ore., R. I., S. D., and Wis.); N. H. and Iowa have adopted the distilled spirits and wine labeling requirements, and Calif., Mich. and Wash. have adopted the distilled spirits labeling requirements alone. State adoption is, of course, usually limited to such provisions as are not in conflict with the provisions of the state law and, in some cases, it is further limitedl by the juris* dictional limitations of the agency itself. In a $\mathrm{few}$ instances the adoption of the advertising regulations is limited to the prohibition of representations from advertising and does not include the mandatory information requirements.

${ }^{80}$ E.g., Idaho, Me. and Va. have issued extensive and detailed advertising regulations of which the adoption of the federal regulations forms a foundation, covcring advertising material, for the state's more specific requirements.

${ }^{81}$ This situation occurs, for example, in Idaho, Ind., Pa., Tenn., Tex. and W. Va.

${ }^{82}$ In Ohio, Calif., Minn., the latter method is followed. ${ }^{83}$ F. A. A. ADMr., ANN. Reps. (1937-1939). 
tion not to carry distilled spirits advertising ${ }^{84}$ has limited the use of this medium by distillers, it has been used to an increasing degree by retailers of distilled spirits and by producers, wholesalers, and retailers of wines and malt beverages. The former Administrator expressed the opinion that this form of advertising was especially dangerous since it enters directly into the home and the family circle and brings the advertised product forcibly to the attention of those who are conscientiously opposed to it, and of those who are not proper prospective consumers. ${ }^{85}$ The results of the questionnaire on advertising submitted to the liquor control agencies of the various states (referred to above) indicated that an overwhelming majority of these agencies shared his views. ${ }^{86}$

In $r 939$ a bill to amend the Federal Alcohol Administration Act was introduced before Congress, which, among other things, added radio advertising to the practices prohibited by Section 5 of the act, but no action was taken thereon. ${ }^{87}$ Several other bills prohibiting varying types of liquor advertising in interstate commerce have been introduced. ${ }^{88}$ The only measure of this kind which has been reported out of committee favorably is S. 517 which was introduced at the first session of the 76 th Congress by Senator Johnson, of Colorado. ${ }^{89}$ This bill is the successor to S. $355^{\circ}$ which he introduced the year preceding at the last session of the $75^{\text {th }}$ Congress, but which

81 The resolution referred to read: "Resolved, that it is the sense of the National Association of Broadcasters Board of Directors that American broadcasting stations should not carry advertising for distilled spirits, commonly called hard liquor."

S5 The former Administrator expressed this view in addresses delivered on several occasions: ( $I$ ) Before the National Retail Liquor Package Stores convention in Chicago, Ill., on Feb. 22, 1937, (2) before the National Conference of State Liquor Administrators on Mackinac Island, Mich., July 19, 1937, (3) before the National Conference of State Liquor Administrators at St. Paul, Minn., June 13, 1938, (4) before the National Alcoholic Beverages Control Association at Columbus, Ohio, April 19, 1939, (5) before the National Retail Liquor Package Stores convention at Boston, Mass., June 13, I939, and (6) before the National Alcoholic Beverages Control Association at Bretton Woods, N. H., Sept. 6, r939.

${ }^{80}$ Fifteen agencies expressed themselves as opposed to the use of this medium for liquor advertising and only one was opposed to its prohibition.

${ }^{87}$ H. R. 6219. The proposed amendment read: "(g) Radio Advertising.-It shall be unlawful for any person required to secure a basic permit under the provisions of this Act, or for any other person, or for any person for, or in behalf of such persons, to broadcast or cause to be broadcast, directly or indirectly, by means of radio, any advertisement of an alcoholic beverage, nor shall any such persons or any person for, or in their behalf, pay for or sponsor, directly' or indirectly, any radio program, or be mentioned in any radio advertisement if, either by use of a trade name or otherwise, reference is made to the fact that such person is engaged in the manufacture, sale, or other distribution of any alcoholic beverage." This bill was introduced in the House of Representatives by Mr. Doughton of North Carolina (by request) and was referred to the Committce on Ways and Means.

${ }^{88}$ E.g., A Bill to Amend the Communications Act to Prohibit the Advertising of Alcoholic Beverages by Radio. H. R. 9624, 75th Cong., 3 d Sess. (1938); A Bill to Prohibit the Transportation in Interstate Commerce of Advertisements of Intoxicating Liquors, etc., H. R. 253, S. 575, 76th Cong., Ist Sess. (x939). The first of these bills made it unlawful to broadcast or to permit the broadcasting of any advertisement or information concerning any alcoholic beverage with the intent of inducing the purchase thereof, subject to a maximum fine of \$rooo or imprisonment for not more than a year, or both; the latter prohibited any producer, wholesaler or retailer, publisher, common carrier, or private carrier for hire to mail or otherwise transport any "newspaper, periodical, newsreel, photographic film, or record for mechanical reproduction advertising intoxicating liquor" or soliciting orders for intoxicating liquor as defined by the laws of the state or territory into which the advertisement or solicitation is transported and also prohibited the broadcasting by means of a licensed radio station of any such advertisement, subject to a maximum fine of \$rooo or imprisonment for not more than 6 months, or both.

${ }^{80}$ Similar bills (H. R. 251, 252) were introduced in the House of Representatives by Mr. Culkin at the same session and were referred' to the House Committee on Interstate and Foreign Commerce. 
was not reported on by the Senate Committee on Interstate Commerce. In its original form, S. $5^{17}$ was identical with $H$. R. 9624 at the same session; however, as reported out by the Committee, it was revised by adding one additional section conditioning all permits issued under the Federal Alcohol Administration Act upon compliance with its provisions and directing the Administrator to revoke or suspend permits for a willful violation thereof.90

It was the opinion of the majority ${ }^{91}$ of the Committee that the bill would apply "merely to commercial advertising of liquor over the radio and would not affect any right of free speech or public discussion of the liquor question by any citizen or group of citizens." The minority report of Senator Gurney objected mainly to singling out for elimination liquor advertising over the radio, and stated that only $5 \%$ of all expenditures for liquor advertising occurred in this field. The minority report appears to be based upon the assumption that there is no necessity for the bill, that it discriminates against the radio industry, and that it would be harmful to the brewing industry. It urges that any abuses that may occur in radio advertising can be corrected by the self-regulation of the industry, or by the Government under the Federal Communications Act, the Federal Trade Commission Act, or the Federal Alcohol Administration Act.

In discussing $S .5^{17} 7$ on the floor of the Senate, ${ }^{92}$ Senator Johnson strongly criticised Senator Gurney's attack on the bill, objected to its being considered fanatical legislation, and to the attempt to have it taken up with S. 575. He pointed out that radio broadcasting is a public utility and that therefore advertisements over the radio are in an entirely different category from advertisements appearing in newspapers and magazines. Senator Johnson has attempted to have this measure considered by the Senate, but it has not yet been brought to a vote. ${ }^{93}$

Although there is no longer any question but that Congress has the power to regulate, under the commerce clause, the transmission of messages by means of radio broadcasting, ${ }^{94}$ it may be argued in connection with this legislation that this power to regulate would not support a statute prohibiting outright the use of radio broadcasting for a particular type of advertising material unless such material was in itself immoral or harmful.95 It should, however, be pointed out that the Supreme Court has already included liquor among the special category of dangerous articles which are subject to an unusually broad power of regulation by Congress. ${ }^{96}$

\footnotetext{
${ }^{\circ 0}$ S. 517, Calendar No. 362, 76 th Cong., ist Sess., as reported.

${ }^{21}$ The majority report upon the bill contains the following significant statement as to its origin: "Following the recommendations of the Federal Alcohol Administration, many times repeated, and the urgent request of hundreds of thousands of parents petitioning Congress for the protection of their homes against offensive vocal advertising, Senator Edwin C. Johnson introduced S. 517. Later the bill was amended upon the suggestion of the Treasury Department to simplify the cnforcement features of the bill." SEN. REP. No. 338, 76th Cong., Ist Sess. (1939).

${ }_{92} 84$ Cong. Rec. 15169-15174, Aug. 3, 1939. 0386 Cong. Rec. 2473, Feb. 19, 1940.

ot Fishers Blend Station, Inc. v. State Tax Comm., 297 U. S. 650 (I936); Fed. Radio Comm. v. Nelson Bros. Bond \& Mortgage Co., 289 U. S. 266 (1933).

${ }^{95}$ Champion v. Ames, I 88 U. S. 32 I (1903); Hipolite Egg Co. v. United Statcs, 220 U. S. 45 (rgrr); Webber v. Freed, 239 U. S. 325 (19I5).

${ }^{90}$ See Clark Distilling Co. v. Western Md. R. R., 242 U. S. 3 II, 332 (I915).
} 